\title{
Evolution of the central Mediterranean Centaurea cineraria group (Asteraceae): Evidence for relatively recent, allopatric diversification following transoceanic seed dispersal
}

\author{
Andreas Hilpold, ${ }^{1}$ Peter Schönswetter, ${ }^{2,3}$ Alfonso Susanna, ${ }^{1}$ Núria Garcia-Jacas ${ }^{1}$ \& Roser Vilatersana ${ }^{1}$ \\ 1 Institut Botànic de Barcelona (CSIC - ICUB), Pg. del Migdia s/n, 08038 Barcelona, Spain \\ 2 Department of Biogeography, Faculty Centre of Biodiversity, University of Vienna, Rennweg 14, 1030 Vienna, Austria \\ 3 Unit of Plant Evolution and Diversity, Institute of Botany, University of Innsbruck, Sternwartestraße 15, \\ 6020 Innsbruck, Austria \\ Author for correspondence: Andreas Hilpold, andreas.hilpold@yahoo.de
}

\begin{abstract}
We explored the spatiotemporal diversification of the Centaurea cineraria group based on AFLP fingerprints and plastid DNA sequences applied to a broad sampling of Central Mediterranean taxa of the Acrolophus subgroup. Despite its morphological distinctness, monophyly of the C. cineraria group was not supported by our data. A distinct lineage mostly restricted to Sicily (the Sicily group) comprised some members of the C. cineraria group but also included C. parlatoris, assumed to be a member of the $C$. dissecta group. The relationships of the Sicily group with other members of the Acrolophus subgroup could not be clarified. Molecular dating supported recent, presumably allopatric diversification whose onset dates back to less than 250,000 years within the Sicily group. Tunisia, the Aeolian Islands and the Island Ventotene in the central Tyrrhenian Sea were likely colonised from Sicily. The young age of diversification within the Sicily group rejects land bridges between Africa and Sicily, which were only available during significantly older periods, in favour of transoceanic seed dispersal. Dispersal might have been favoured by low sea levels during cold stages of the Pleistocene. The molecular data indicate that taxonomy of the C. cineraria group needs to be revised..
\end{abstract}

Keywords AFLP; biogeography; Mediterranean; phylogeography; Sicily; transoceanic dispersal

\section{口 INTRODUCTION}

The Mediterranean is one of the global centres of biodiversity (Myers \& al., 2000) owing to a complex geographic and climatic history (Thompson, 2005). Moreover, the Mediterranean Basin is situated at the crossroads of three continents and has served as meeting ground and eventually melting pot for a variety of lineages (Blondel \& Aronson, 1999). A plethora of diversification processes resulted in a highly "reticulate" biogeographical history (Sanmartín, 2003). The overall richness of about 25,000 plant species (Quézel, 1985) is to a large extent due to the presence of a high number of locally or regionally endemic taxa (Greuter, 1991; Médail \& Diadema, 2009). Islands and mountain ranges are known for their richness (Médail \& Quézel, 1997), with mountainous islands exhibiting the highest rates of species diversity and endemism. One such example is Sicily: with 2,700 plant species it is the island with the greatest species richness in the Mediterranean (Raimondo \& al., 1994; Médail \& Quézel, 1997; Giardina \& al., 2007) and is considered one of ten "hot spots" of biodiversity within the Mediterranean (Médail \& Quézel, 1997). The percentage of endemics among vascular plants ranges from $10 \%$ to $20 \%$ in the mountainous interior part of the island (Médail \& Quézel, 1997; Conti \& al., 2005). In addition to complex history (see below), a precondition for biotic diversity is a highly diverse landscape. Coastal regions of the island harbour evergreen, thermo-mediterranean vegetation whereas the top of Mt. Etna, Europe's highest active volcano, is snow-covered for most of the year. In between, a wide range of natural and anthropogenic habitats on both volcanic and calcareous substrate can be observed. This natural diversity offered an outstanding playground for evolutionary processes during an eventful geographical and geological history.

Sicily existed as an island through most of the Miocene (23.0-5.3 Ma [million years]; Meulenkamp \& Sissingh, 2003; Goes \& al., 2004), and was in tight contact with Calabria (S. Italy), Corsica, and Sardinia especially during late stages of this epoch (Speranza \& al., 2002; Goes \& al., 2004). Consequently, Sicily has probably had an important function as migration route and stepping stone between Africa and Europe and between the eastern and the western Mediterranean (shown for Centaurea subg. Acrocentron; Font \& al., 2009). The connection with Corsica and Sardinia is evidenced, for example, in Araceae (Mansion \& al., 2008). A direct connection with the African continent certainly existed during the Messinian Salinity Crisis (MSC, 5.96-5.33 Ma), when the Mediterranean desiccated due to the closure of the Strait of Gibraltar (Hsü \& al., 1972; Butler \& al., 1999; Krijgsman \& al., 1999). With the end of the MSC, Sicily became an island again (Blanc, 2002; Garcia-Castellanos \& al., 2009). The Strait of Sicily functioned as barrier between Sicily and Africa, whereas the Strait of Messina and the Isthmus of Catanzaro were barriers between Sicily and the Italian mainland (Bonfiglio \& al., 2002). This fact, in combination with the subsequent onset of the Mediterranean climate around 3.2-2.8 Ma (Suc, 1984; 
Thompson, 2005), may have been crucial for the development of a specific Sicilian flora. The Pleistocene climatic oscillations led to strong sea level fluctuations (Rohling \& al., 1998). During warm periods, the island was much more isolated than during cold periods, when the sea level was $120-150 \mathrm{~m}$ below the recent level (Rohling \& al., 1998; Lambeck \& Bard, 2000; Lambeck \& al., 2004). The distance to Africa was only 50 km during the Last Glacial Maximum (Thiede, 1978; Stöck \& al., 2008), i.e., less than half of today's distance. The Strait of Messina was almost or entirely closed and various small islands around Sicily were connected to the main island (Lambeck \& al., 2004). However, there is no evidence for a land bridge to Africa after the MSC.

The islands to the north of Sicily originated from volcanic eruptions during the last one million years. The larger Aeolian Islands in the Southern Tyrrhenian Sea were formed between 430,000 and 120,000 years BP (Barca \& Ventura, 1991; Crisci \& al., 1991; Astis \& al., 1997), and the rise of Ventotene and Ponza situated in the northern Tyrrhenian Sea happened more or less at the same time (Bellucci \& al., 1999). The distance of the Aeolian Islands to Sicily is small suggesting that their colonisation may have taken place mostly from Sicily. The islands in the northern Tyrrhenian Sea, however, are close to the Italian mainland rendering colonisation from there more probable.

Despite its biotic richness and the high number of endemics, Sicily has been largely neglected in phylogeographic studies. In contrast, disjunctions across the Strait of Gibraltar have been examined in detail (e.g., Martínez-Solano \& al., 2004; Veith \& al., 2004; Busack \& Lawson, 2008; Cano-Maqueda \& al., 2008; Ortiz \& al., 2009). Most phylogeographic studies concerning Sicily and the adjacent areas affect a broader region, such as the entire central or western Mediterranean, and are primarily phylogenetic (e.g., Mansion \& al., 2008). Whereas the paramount role of the MSC for plant migrations was emphasised for Holm Oak (Quercus ilex L., Lumaret \& al., 2002), other studies demonstrated post-Messinian diversifications (Matthiola W.T. Aiton: Sánchez \& al., 2005; Jacobaea Mill.: Passalacqua \& al., 2008; Anthemis L.: Lo Presti \& Oberprieler, 2009).

A good model to explore biogeographic relationships among Sicily, Northern Africa, the Apennine Peninsula and the islands of the Tyrrhenian Sea is provided by the relatives of Centaurea cineraria, perennial herbs with tomentose leaves and purple florets. They belong to the morphologically defined C. sect. Acrolophus (Candolle, 1838), which was combined with $C$. sect. Phalolepis and sect. Willkommia to create the molecularly defined, monophyletic "Acrolophus subgroup" of the "Jacea group" (Garcia-Jacas \& al., 2006; Suárez-Santiago \& al., 2007b; Hilpold \& al., 2009). The Jacea group was suggested to have originated in the late Miocene in the eastern Mediterranean (Suárez-Santiago \& al., 2007b). The classification of the Acrolophus subgroup is not sufficiently resolved as extensive hybridisation has likely played a key role in its evolution (Suárez-Santiago \& al., 2007b). The C. cineraria group (Pignatti, 1982; Cela-Renzoni \& Viegi, 1982; Raimondo \& Bancheva, 2004; Raimondo \& al., 2004) comprises ten species, three of which are further divided into subspecies
(C. cineraria, C. aeolica, C. panormitana). Four species occur in Sicily (C. busambarensis, C. erycina, C. panormitana, $C$. saccensis), three grow in adjacent areas (C. aeolica on islands of the southern and central Tyrrhenian Sea, C. cineraria on the southwestern coast of the Apennine Peninsula and C. papposa in Tunisia), two more around the northern Tyrrhenian Sea (C. gymnocarpa and C. veneris) and C. leucadea at the southeastern tip of Italy (Fig. 1). To date, it is unclear if the latter three species belong to the $C$. cineraria group. It is noteworthy that $C$. aeolica is a rare example of a species which inhabits the two different volcanic island archipelagos of the Tyrrhenian Sea; subsp. aeolica occurs on the Aeolian Islands while subsp. pandataria occurs on Ventotene offshore Naples. All members of the $C$. cineraria group inhabit rocky places, predominantly coastal cliffs. Sicily is the only area where species occur in mountain areas (C. busambarensis and C. erycina) and $C$. saccensis is restricted to an inland gorge. The preferred bedrock is mostly calcareous; an exception is $C$. aeolica from volcanic islands. All species except $C$. gymnocarpa possess achenes with a pappus, but the achene is glabrous, fairly heavy and the pappus is short. Consequently, gravity appears to be the only mechanism of seed dispersal (Bancheva, unpub.). In C. corymbosa Pourr., a close relative of the $C$. cineraria group (Hilpold \& al., 2009), the average seed dispersal distance was only $32 \mathrm{~cm}$ (Colas \& al., 1997; Hardy \& al., 2004). Pollination is mainly carried out by insects (Cela-Renzoni \& Viegi, 1982) and reproduction is mostly sexual, but facultative apospory was reported in C. cineraria, C. gymnocarpa and C. panormitana (Cela-Renzoni \& Viegi, 1982). The chromosome number is $2 n$ $=18$ (Cela-Renzoni \& Viegi, 1982; Raimondo \& Bancheva, 2004), only a single tetraploid individual was ever counted (Damboldt \& Matthäs, 1975).

Although several molecular studies were conducted in the Acrolophus subgroup (Ochsmann, 2000; Garcia-Jacas \& al., 2006; Suárez-Santiago \& al., 2007a,b), the C. cineraria group has been fairly neglected with only a single isoenzyme study available (Bancheva \& al., 2006). Here, we apply complementary molecular markers, i.e., maternally inherited (Zhang \& al., 2003), slowly evolving plastid DNA sequences and biparentally inherited, rapidly evolving (Bussell \& al., 2005) AFLPs to a dense population sampling throughout the distribution area of all taxa of the $C$. cineraria group plus an exhaustive sample of potential outgroups. Our aim is to answer the following questions. (1) Does the $C$. cineraria group constitute a natural, monophyletic entity and which species of the Acrolophus subgroup in the Central Mediterranean are the next relatives? (2) If the $C$. cineraria group is monophyletic, at what time did it diversify? (3) Furthermore, we test the two hypotheses for the origin of the disjunction across the strait of Sicily, i.e., vicariance due to the fragmentation of a land-bridge established during the Messinian Salinity Crisis or transoceanic seed dispersal. (4) In addition, we aim to elucidate the phylogenetic relationships of the two subspecies of $C$. aeolica from geographically distant volcanic islands in the Tyrrhenian Sea in order to trace their colonisation history. Finally (5), we point out shortcomings of the presently used taxonomic framework. 


\section{MATERIALS AND METHODS}

In the summer of 2008, 30 sample sites (subsequently referred to as "populations") of Centaurea sect. Acrolophus, sect. Phalolepis and sect. Willkommia were visited in the field (Fig. 1; Table 1). In addition to all taxa of the $C$. cineraria group, we also included southern Italian members of the two other groups constituting sect. Acrolophus, i.e., the C. paniculata and C. dissecta groups (Pignatti, 1982) as well as C. argentea, a member of sect. Acrolophus from Crete. Centaurea subtilis Bertol. was not included, as it belongs to the Jacea-Lepteranthus clade (Hilpold \& al., 2009) rather than to the C. cineraria group. Voucher specimens were determined based on Pottier-Alapetite (1981), Pignatti (1982), Breitwieser \& Podlech (1986), Turland \& Chilton (2000), Arrigoni (2003), Raimondo \& Bancheva (2004) and Raimondo \& al. (2004). Nomenclature follows Greuter (2008) and Peruzzi (2008). Leaf material was collected and immediately stored in silica gel. Voucher specimens are deposited at the herbarium of the Institut Botànic de Barcelona (BC).

Total genomic DNA was extracted from silica gel-dried tissue (ca. $10 \mathrm{mg}$ ) of eight to ten plants from each population (only two plants in population 13). Extraction followed the
CTAB-protocol of Doyle \& Doyle (1987) with the modifications of Tel-Zur \& al. (1999), including three washing steps with sorbitol buffer and a few further modifications: after precipitation with isopropanol and subsequent centrifugation, the DNA pellet was washed in $70 \%$ ethanol, dried at $37^{\circ} \mathrm{C}$ and re-suspended in TE-buffer. The quality of the extracted DNA was checked on $0.7 \%$ TBE agarose gels.

The AFLP procedure followed Vos \& al. (1995) with the modifications described in Schönswetter \& al. (2009). Initially, selective primers were screened using 24 selective primer combinations. The two final primer combinations for the selective PCR (fluorescent dye in brackets) were EcoRI (6-Fam)-ACA/ $M s e I-C A C$ and EcoRI (NED)-AGC/MseI-CTG. Five microlitres of each selective PCR product were combined and purified using Sephadex G-50 Superfine (GE Healthcare Bio-Sciences, Uppsala, Sweden) applied to a Multi Screen-HV plate (Millipore, Molsheim, France). One microlitre of the elution product was mixed with $10 \mu \mathrm{l}$ formamide (Applied Biosystems, Foster City, California, U.S.A.) and $0.1 \mu$ GeneScan 500 ROX (Applied Biosystems) and run on an ABI 3130x automated capillary sequencer. Nineteen individuals were used as replicates to calculate the error rate and to exclude non-reproducible fragments from the analysis. Raw AFLP data were aligned with
Fig. 1. Sampled populations of Centaurea in the central Mediterranean and in Crete. Details of the collected populations are given in Table 1. Symbols reflect the taxonomic framework of Pignatti (1982) and Breitwieser \& Podlech (1986).

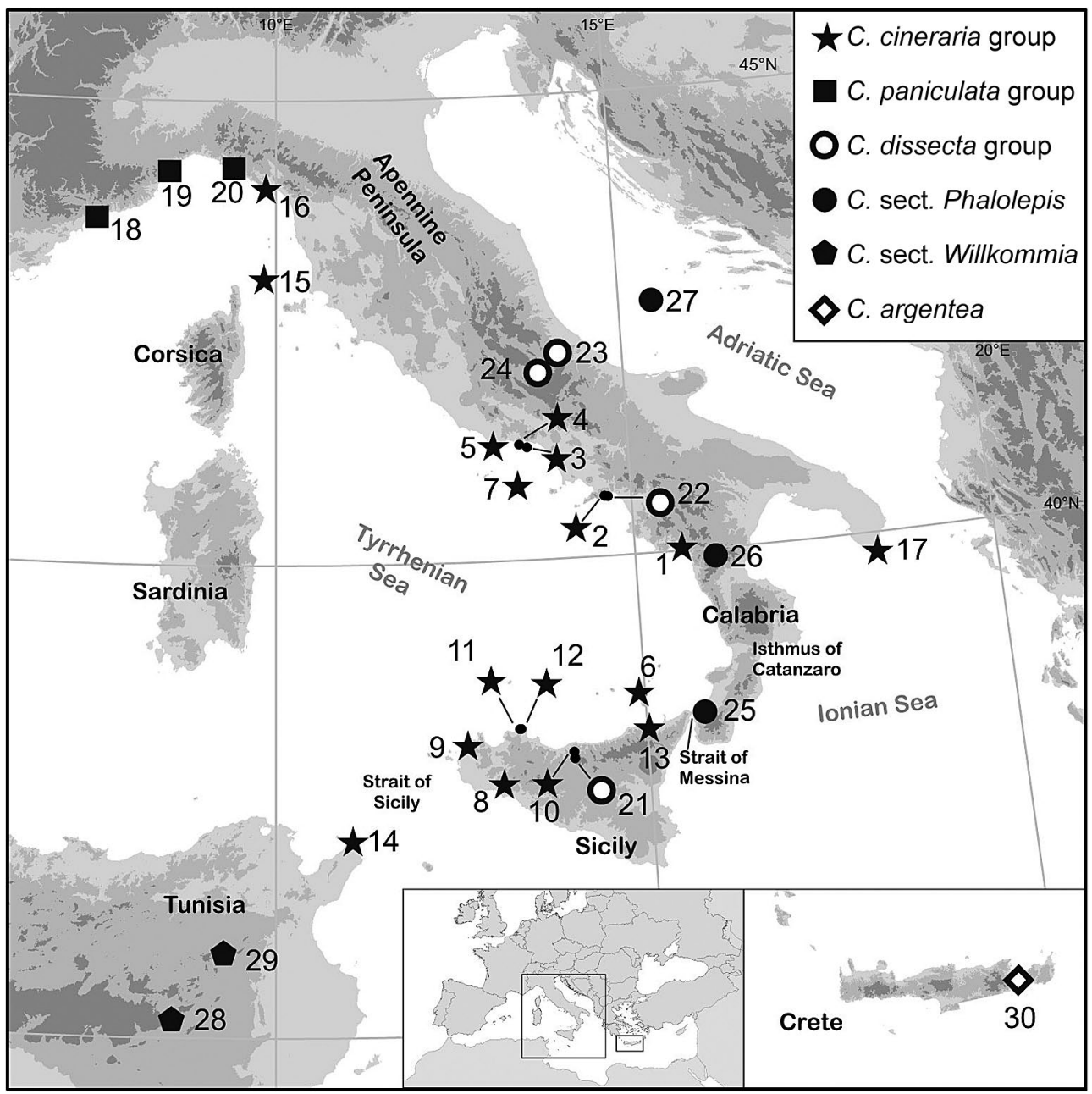


the internal size standard using ABI Prism GeneScan v.3.7.1 (Applied Biosystems), and imported into Genographer v.1.6.0 (available at http://hordeum.oscs.montana.edu/genographer) for scoring. The error rate (Bonin \& al., 2004) was calculated as the ratio of mismatches (scoring of 0 vs. 1) over matches (1 vs. 1) in the AFLP profiles of replicated individuals.

A Neighbour-joining (NJ) analysis based on a Nei-Li distance matrix (Nei \& Li, 1979) was conducted and bootstrapped (2000 pseudo-replicates) with TreeCon $1.3 \mathrm{~b}$ (Van de Peer \& De Wachter, 1997). Population mixture analysis implemented in BAPS v.5.2 (Corander \& al., 2004) was used to infer the genetic structure of the Sicily group (see Results for a definition). This software can handle dominant markers like AFLPs under the module "clustering with linked loci" (Corander \& Tang, 2007). Mixture analysis was conducted with the maximal number of groups $(\mathrm{K})$ set to 2 to 10 . Each run was replicated ten times and the results were averaged according to the resultant likelihood scores. Admixture coefficients were estimated using 500 iterations, and the significance of these coefficients was estimated by employing the simulation strategy described by Corander \& Marttinen (2006) using 50 reference individuals and 10 iterations each. An Unweighted Pair Group Method with Arithmetic mean (UPGMA) tree among clusters was inferred based on Nei distances.

Out of several plastid DNA markers screened, only the rpl32-trnL intergenic spacer (primers rpl32-F, trnL (UAG); Shaw \& al., 2007) showed a sufficient degree of variation, while other markers were either entirely invariable or exhibited only very few variable sites. This result is in accordance with the survey of Shaw \& al. (2007), who identified the rpl32-trnL intergenic spacer as the most variable plastid DNA region out several tested. It was sequenced from five to six individuals per population from the Sicily group and the geographically distant $C$. argentea. Reactions were performed in $25 \mu \mathrm{l}$ volumes with $2.5 \mu 1$ 10× AmpliTaq buffer, $2.5 \mu 125 \mathrm{mM} \mathrm{MgCl}_{2}$, $2.5 \mu \mathrm{l} 2 \mathrm{mM}$ dNTPs mix, $1 \mu \mathrm{l}$ of each primer at $5 \mu \mathrm{M}, 2.5 \mu \mathrm{l}$ of $400 \mathrm{ng} / \mu \mathrm{l}$ BSA (bovine serum albumine; New England Biolabs, Ipswich, Massachusetts, U.S.A.), 1 U AmpliTaq DNA polymerase (Applied Biosystems) and $2 \mu 1$ of template DNA of unknown concentration. PCR was conducted using the following conditions: $3 \mathrm{~min}$ at $95^{\circ} \mathrm{C}$, followed by 35 cycles of $95^{\circ} \mathrm{C}$ for $40 \mathrm{~s}, 54^{\circ} \mathrm{C}$ for $40 \mathrm{~s}$ and $72^{\circ} \mathrm{C}$ for $1 \mathrm{~min} 40 \mathrm{~s}$, followed by $10 \mathrm{~min}$ at $72^{\circ} \mathrm{C}$. The PCR product was purified with ExoSAP-IT (USB Corp., Cleveland, Ohio, U.S.A.). Direct sequencing of the amplified DNA segments was performed using BigDye Terminator Cycle Sequencing v.3.1 (Applied Biosystems), following the manufacturer's protocol at the University of Florida ICBR Core Facility on an ABI 3730xl capillary sequencer (Applied Biosystems). Nucleotide sequences were edited using BioEdit v.7.0.5.3 (Hall, 1999) and were aligned manually.

A statistical parsimony haplotype network was constructed using TCS v.1.21 (Clement \& al., 2000). For the latter analysis, insertions/deletions longer than one base pair were re-coded as single base pair mutations, and sequence gaps were treated as a fifth character state.

Molecular dating of the onset of plastid DNA diversification within the Sicily group was conducted using BEAST v.1.5.3
(Drummond \& Rambaut, 2007). The best substitution model had an Akaike weight (determined with Modeltest v.3.6; Posada $\&$ Crandall, 1998) of 0.31 and 17 models (out of 56 tested) were included until the cumulative Akaike weight exceeded 0.95. The included models ranged from having only three (F81) up to eight free parameters, and for the final analysis we used HKY + Gamma which is a medium complex model with five free parameters, using six rate categories instead of the default four. Given the low level of sequence variation within the Sicily group (see Results), we used a strict clock model with a prior on the substitution rate modelled as a lognormal distribution and a model of constant population size as demographic model. Setting a rate of $4.5 \times 10^{-3}$ substitutions per site and per million years and a deliberately wide standard deviation of $3 \times 10^{-2}$ resulted in the mode of the prior distribution at $4.0 \times 10^{-3}$ substitutions per site and per million years in accordance with published substitution rates for plastid markers (Yamane \& al., 2003; Smith \& al., 2008). After initial analyses, the root of the tree was constrained to be maximally 5 million years old. The Markov chain was run three times for $5 \times 10^{7}$ generations each, sampling every 1000th generation. After removing the first $10 \%$ of sample points as burn-in, parameter estimates and their $95 \%$ highest posterior density intervals (HPD) were obtained from 135,000 generations.

\section{- RESULTS}

We scored 476 AFLP fragments ranging from 100 to 550 base pairs. The error rate amounted to $4.7 \%$ and was thus within the range deemed acceptable by Bonin \& al. (2004). Neighbourjoining analysis (Fig. 2) linked all individuals of each population to separate clusters with bootstrap support (BS) between $94 \%$ and $100 \%$. Exceptions were the two geographically close populations of $C$. panormitana (populations 11 and 12) as well as $C$. delicatula (population 28). One individual of C. busambarensis (population 10) grouped with low support (BS 51\%) with C. parlatoris (population 21). Centaurea argentea (population 30) was separated along the longest branch in an unrooted NJ analysis and was therefore used to root the tree. Only a few deeper nodes had BS $>50 \%$. A branch formed by C. leucadea, C. deusta and C. scillae (populations 17, 26, 25, respectively) was sister to all other populations with BS $60 \%$. Within this latter group three members of the C. paniculata group s.str. and $C$. veneris constituted a branch with BS $81 \%$. The best supported larger group within the tree consisted of nine populations of the $C$. cineraria group from Sicily, the Tyrrhenian Islands and Tunisia and $C$. parlatoris from Sicily. The group received BS 93\% and is referred to as the Sicily group. The Sicily group was split into two smaller groups with low support, the first consisting of the two subspecies of $C$. aeolica from the Tyrrhenian Islands and the Tunisian C. papposa, the second consisting of all populations from Sicily.

Mixture analysis of the Sicily group identified eight clusters that consisted mainly of single populations or several populations of the same taxon, with the exception of a cluster joining C. parlatoris (population 21), C. panormitana subsp. 
seguenzae (population 13) and one individual of C. busambarensis (population 10). The UPGMA tree among the clusters identified two main groups (Fig. 3A). The first was distributed from Tunisia over Sicily to the islands of the central and northern Tyrrhenian and comprised two subgroups, constituted by $C$. saccensis (population 8) plus the Tunisian C. papposa (population 14), and by C. aeolica subsp. aeolica (population 6) plus subsp. pandataria (population 7). The second group was restricted to Sicily and fell into a northwestern (populations 9, 11,12 ) and an eastern subgroup (populations 10, 21, and 13).
The subsequent admixture analysis revealed admixture in a single individual from population 13 and is presented on a geographical basis in Fig. 3C.

The rpl32-trnL sequences of members of the Sicily group were $843-867$ bp long and yielded six haplotypes altogether (Tables 1-2; Fig. 3B). Haplotype IV occurred in six populations (Fig. 3C): C. busambarensis (population 10), C. parlatoris (population 21), both subspecies of C. aeolica (populations 6 and 7), C. erycina (population 9) and C. papposa (population 14). The haplotypes of the remaining populations differed only in a

Table 1. Population number (Pop.), taxon, collecting locality and collection number, coordinates, number of individuals investigated with AFLPs, cpDNA haplotype for members of the Sicily group (for a definition, see text) and GenBank accession numbers of 30 sampled populations of ...

\begin{tabular}{|c|c|c|}
\hline & Pop. & Taxon \\
\hline \multirow[t]{17}{*}{ C. cineraria group } & 1 & Centaurea cineraria L. subsp. cineraria \\
\hline & 2 & Centaurea cineraria L. subsp. cineraria \\
\hline & 3 & Centaurea cineraria L. subsp. cineraria \\
\hline & 4 & Centaurea cineraria L. subsp. cineraria \\
\hline & 5 & Centaurea cineraria L. subsp. circae (Sommier) Cela Renz. \& Viegi \\
\hline & 6 & Centaurea aeolica Lojac. subsp. aeolica \\
\hline & 7 & Centaurea aeolica Lojac. subsp. pandataria (Fiori \& Bég.) Anzal. \\
\hline & 8 & Centaurea saccensis Raimondo \& al. \\
\hline & 9 & Centaurea erycina Raimondo \& Bancheva \\
\hline & 10 & Centaurea busambarensis Guss. \\
\hline & 11 & Centaurea panormitana Lojac. s.1. \\
\hline & 12 & Centaurea panormitana Lojac. s.1. \\
\hline & 13 & Centaurea panormitana Lojac. subsp. seguenzae (Lacaita) Greuter \\
\hline & 14 & Centaurea papposa (Coss.) Greuter \\
\hline & 15 & Centaurea gymnocarpa Moris \& De Not. \\
\hline & 16 & Centaurea veneris (Sommier) Bég. \\
\hline & 17 & Centaurea leucadea Lacaita \\
\hline \multirow[t]{3}{*}{ C. paniculata group } & 18 & Centaurea leucophaea Jord. subsp. controversa (Briq. \& Cavill.) Kerguélen \\
\hline & 19 & Centaurea aplolepa Moretti subsp. aplolepa \\
\hline & 20 & Centaurea aplolepa Moretti subsp. levantina (Arrigoni) Greuter \\
\hline \multirow[t]{4}{*}{ C. dissecta group } & 21 & Centaurea parlatoris Heldr. \\
\hline & 22 & Centaurea lacaitae Peruzzi \\
\hline & 23 & Centaurea ambigua Guss. \\
\hline & 24 & Centaurea scannensis Anzal. \& al. \\
\hline \multirow[t]{3}{*}{ Centaurea sect. Phalolepis } & 25 & Centaurea scillae Brullo \\
\hline & 26 & Centaurea deusta Ten. \\
\hline & 27 & Centaurea diomedea Gasp. \\
\hline \multirow[t]{2}{*}{ Centaurea sect. Willkommia } & 28 & Centaurea delicatula Breitw. \& Podlech \\
\hline & 29 & Centaurea delicatula Breitw. \& Podlech \\
\hline Centaurea sect. Acrolophus (Incertae sedis) & 30 & Centaurea argentea L. subsp. argentea \\
\hline
\end{tabular}


few mutational steps from haplotype IV. Haplotypes from populations 2 and 5 of the outgroup C. cineraria were also linked directly to this haplotype. Centaurea argentea (population 30) is separated from haplotype IV by five mutational steps.

Using a model of constant population size, the onset of diversification within the Sicily group was inferred to be (given as mean/median) $0.248 / 0.207 \mathrm{Ma}$ (95\% highest posterior density interval $0.576-0.018 \mathrm{Ma})$. The use of a more complex demographic model (extended Bayesian Skyline Plot) resulted in slightly younger age estimates (not shown).

\section{DISCUSSION}

Despite the clear morphological diagnostic features of the Centaurea cineraria group (Pignatti, 1982, Cela-Renzoni \& Viegi, 1982; Raimondo \& Bancheva, 2004; Raimondo \& al., 2004), our AFLP data suggest that even though most populations are strongly reciprocally divergent, little higher-level structure is evident. Monophyly of the $C$. cineraria group in the traditional circumscription is not supported. Only a mostly geographically defined group centred on Sicily, but also including

... Centaurea from the central Mediterranean and Crete. All vouchers are deposited in the herbarium BC. Collections numbers are those of Vilatersana (V) or Galbany-Casals (G).

\begin{tabular}{|c|c|c|c|c|}
\hline Locality and collection number & Coordinates $(\mathrm{E}, \mathrm{N})$ & NAFLP & Haplotype & GenBank accession \\
\hline Italy, Potenza: Acquafredda, $V-1120$ & $15^{\circ} 39^{\prime} 53^{\prime \prime}, 40^{\circ} 02^{\prime} 21^{\prime \prime}$ & 8 & - & \\
\hline Italy, Salerno: Minori, $V-1118$ & $14^{\circ} 37^{\prime} 48^{\prime \prime}, 40^{\circ} 38^{\prime} 55^{\prime \prime}$ & 10 & - & \\
\hline Italy, Latina: Gaeta, $V-1112$ & $13^{\circ} 34^{\prime} 00^{\prime \prime}, 41^{\circ} 12^{\prime} 30^{\prime \prime}$ & 10 & - & \\
\hline Italy, Latina: Torre Capovento, $V-1107$ & $13^{\circ} 27^{\prime} 45^{\prime \prime}, 41^{\circ} 14^{\prime} 30^{\prime \prime}$ & 10 & - & \\
\hline Italy, Latina: Isola di Ventotene, $V-1113$ & $13^{\circ} 24^{\prime} 55^{\prime \prime}, 40^{\circ} 47^{\prime} 13^{\prime \prime}$ & 9 & IV (6) & HQ441800-HQ441805 \\
\hline Italy, Agrigento: Lago Arancio, V-1159 & $13^{\circ} 03^{\prime} 39^{\prime \prime}, 37^{\circ} 37^{\prime} 35^{\prime \prime}$ & 10 & I (6) & HQ441776-HQ441781 \\
\hline Italy, Trapani: Erice, $V$-1160bis & $12^{\circ} 35^{\prime} 17^{\prime \prime}, 38^{\circ} 02^{\prime} 10^{\prime \prime}$ & 10 & IV (6) & HQ441782-HQ441787 \\
\hline Italy, Messina: Tindari, $V-1173$ & $15^{\circ} 02^{\prime} 27^{\prime \prime}, 38^{\circ} 08^{\prime} 40^{\prime \prime}$ & 2 & III (2) & HQ441763, HQ441764 \\
\hline Tunisia, Nabeul: Cap Bon, V-1384 & $11^{\circ} 01^{\prime} 41.9^{\prime \prime}, 37^{\circ} 04^{\prime} 22.3^{\prime \prime}$ & 9 & IV (6) & HQ441788-HQ441793 \\
\hline Italy, Livorno: Isola di Capraia, V-1248 & $09^{\circ} 50^{\prime} 35^{\prime \prime}, 43^{\circ} 03^{\prime} 00^{\prime \prime}$ & 10 & - & \\
\hline Italy, La Spezia: Palmaria, V-1255 & $09^{\circ} 51^{\prime} 04^{\prime \prime}, 44^{\circ} 02^{\prime} 33^{\prime \prime}$ & 10 & - & \\
\hline Italy, Lecce: S. Maria di Leuca, $V-1205$ & $18^{\circ} 22^{\prime} 22^{\prime \prime}, 39^{\circ} 47^{\prime} 57^{\prime \prime}$ & 10 & - & \\
\hline France, Alpes-Maritimes: Eze, $V-1274$ & $07^{\circ} 21^{\prime} 02^{\prime \prime}, 43^{\circ} 42^{\prime} 59^{\prime \prime}$ & 10 & - & \\
\hline Italy, Savona: Spotorno, $V-1265$ & $08^{\circ} 24^{\prime} 02^{\prime \prime}, 44^{\circ} 13^{\prime} 46^{\prime \prime}$ & 10 & - & \\
\hline Italy, Reggio Calabria: Bagnara, V-1140 & $15^{\circ} 47^{\prime} 07^{\prime \prime}, 38^{\circ} 16^{\prime} 28^{\prime \prime}$ & 10 & - & \\
\hline Italy, Potenza: Prastio, V-1131 & $16^{\circ} 08^{\prime} 13^{\prime \prime}, 39^{\circ} 56^{\prime} 15^{\prime \prime}$ & 10 & - & \\
\hline Italy, Foggia: San Domino, V-1211 & $15^{\circ} 29^{\prime} 42^{\prime \prime}, 42^{\circ} 42^{\prime} 13^{\prime \prime}$ & 8 & - & \\
\hline Tunisia, Siliana: Jebel Seri, V-1346 & $09^{\circ} 23^{\prime} 27.7^{\prime \prime}, 35^{\circ} 51^{\prime} 24.4^{\prime \prime}$ & 9 & - & \\
\hline Tunisia, Kasserine: Jebel ech Chambi, V-1355 & $08^{\circ} 39^{\prime} 53.9^{\prime \prime}, 35^{\circ} 12^{\prime} 09.2^{\prime \prime}$ & 9 & - & \\
\hline Greece, Crete: Kavousi, G-2008 & $25^{\circ} 49^{\prime} 12.2^{\prime \prime}, 35^{\circ} 06^{\prime} 17.4^{\prime \prime}$ & 8 & - & HQ441806 \\
\hline
\end{tabular}


C. papposa from North Africa, C. aeolica from the Tyrrhenian Islands and the morphologically clearly distinct $C$. parlatoris from Sicily form a supported monophyletic entity termed here the "Sicily group". The next relatives of the Sicily group cannot be determined due to insufficient resolution (Fig. 2). Our AFLP data provide no direct evidence that hybridisation, previously suggested to be a driving force in the diversification of Centaurea, is the main cause for the lack of coherence of the $C$. cineraria group. If at all, hybridisation had already occurred in early stages of diversification.

Highly fragmented distribution patterns as exemplified by the $C$. cineraria group were considered indicative for old, "relic" groups that failed to re-gain a wider distribution after restriction to the warmest available habitats such as coastal cliffs during cold stages of the Pleistocene (Ferrarini, 1971; Cela-Renzoni \& Viegi, 1982). In contrast, plastid DNA data generated for the Sicily group strongly discourage an old age but instead suggest a fairly recent diversification taking place less than 250,000 years ago. As suggested by the AFLP data (Fig. 2) albeit without bootstrap support, the closest extant relatives of the Sicily group may be sought for in northern populations of $C$. cineraria subsp. cineraria. In any event, the ancestors of the Sicily group have most probably evolved on the Italian mainland and subsequently dispersed to Sicily. As southernmost Italy is predominated by granitic bedrock, an unsuitable substrate for members of the $C$. cineraria group, long-distance seed dispersal across the Tyrrhenian Sea appears more probable than the significantly shorter crossing of the Strait of Messina.

Diversification within Sicily and further dispersal into circumjacent areas (North Africa, Tyrrhenian Islands) was accompanied by genetic divergence in probably small and isolated populations as well as by rapid morphological diversification. Differentiation of populations may have been fostered by natural habitat fragmentation. Sandy beaches and river estuaries have probably acted as barriers for members of the Sicily group, which are restricted to rock faces close to the sea. Despite the fact that their achenes lack adaptations for long-distance dispersal (Bancheva, unpub.), members of the Sicily group were obviously able to expand their distribution areas. We found the same plastid DNA haplotype in populations from

Fig. 2. Neighbour-joining tree of AFLP data of 30 populations of Centaurea in the central Mediterranean and in Crete. Numbers along branches are bootstrap support values above $45 \%$. As in Fig. 1, symbols reflect the taxonomic framework of Pignatti (1982) and Breitwieser \& Podlech (1986). The Sicily group (for circumscription see text) is shaded in grey.

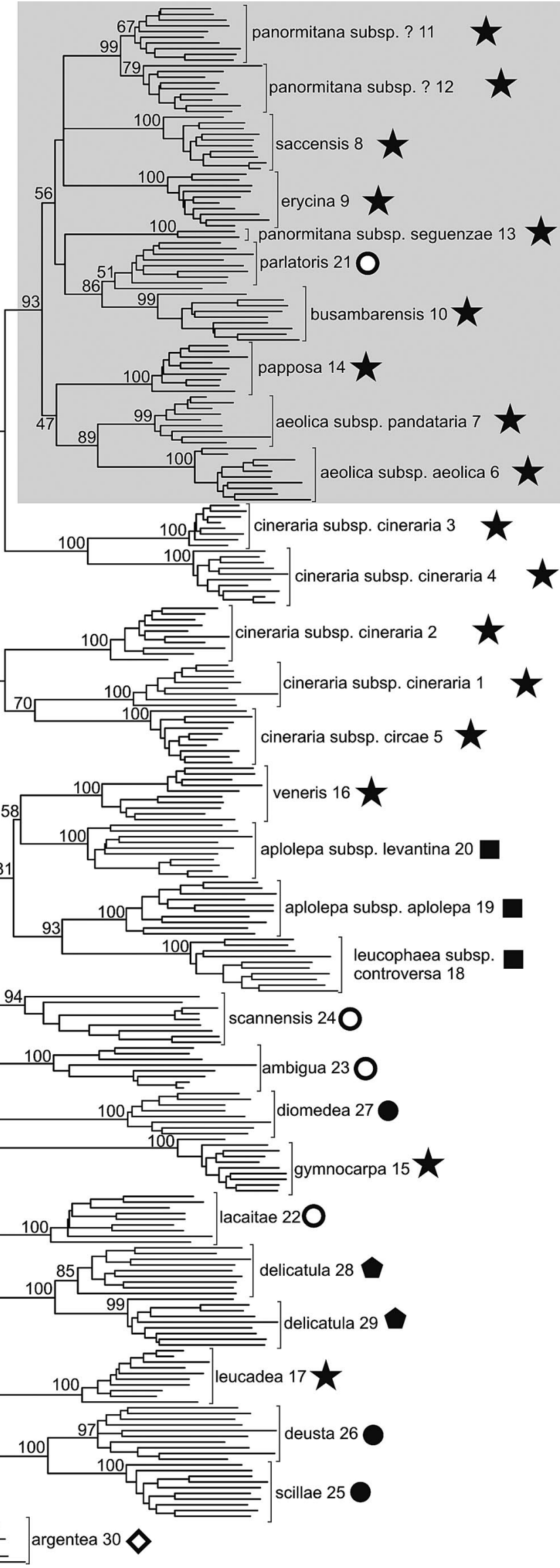


North Africa on the one hand and Sicily and the Tyrrhenian Islands on the other hand (Fig. 3C). As the earliest diversification within the Sicily group clearly post-dates the MSC when a land bridge connected Sicily and Africa, vicariance can be outright rejected as cause for the disjunction in favour of transoceanic seed dispersal. The dispersal from Sicily to northern Africa likely occurred during cold periods of the Pleistocene when the distance between Sicily and Tunisia was much smaller (Thiede, 1978; Stöck \& al., 2008), and may have been easier leaped. Similarly, the disjunction seen in C. aeolica between Lipari and Ventotene over a distance of about $250 \mathrm{~km}$ is best explained by long-distance seed dispersal. The relatively recent emergence of these islands during the last one million years fits well with our dating of the group's diversification. Colonisation likely occurred directly from the Aeolian Islands to Ventotene and Ischia, where the species was reported in the 19th century (Gussone cit. in Pignatti, 1982), but appears to be extinct now. Centaurea aeolica grows on volcanic soil, but the rocks along the coast south of Naples are almost exclusively calcareous or granitic, rendering dispersal across the mainland difficult. Seed dispersal probably occurred during cold periods with lower sea level and may have involved a stepping stone, the volcanic Palinuro seamount that nowadays lies below sea level, but was a large, flat island during cold periods (Kenyon \& al., 2003; Siani \& al., 2004). Similar disjunction patterns between

Fig. 3. AFLP and plastid DNA variation in populations of the Sicily group of Centaurea from Sicily, Tunisia and the Tyrrhenian (for definition, see text). A, Unweighted Pair Group Method with Arithmetic mean (UPGMA) tree based on Nei distances among gene pools derived by Bayesian clustering with BAPS. B, Statistical parsimony network of plastid DNA haplotypes. A mutational step not sampled is given as small black dot. The asterisk shows the connection with haplotypes sampled in the outgroups Centaurea cineraria and C.argentea. C, Geographical distribution of plastid DNA haplotypes derived from $r p l 32-t r n L$ sequences (indicated with roman numerals) and of eight gene pools as defined by Bayesian clustering (indicated in colour). the volcanic area of Naples and the nearby Tyrrhenian Island Ventotene on the one hand and the Aeolian Islands on the other hand are rarely observed; further examples are provided by Bassia saxicola (Guss.) A.J. Scott and Heliotropium suaveolens M. Bieb. subsp. bocconei (Guss.) Brummitt (Pignatti, 1982).

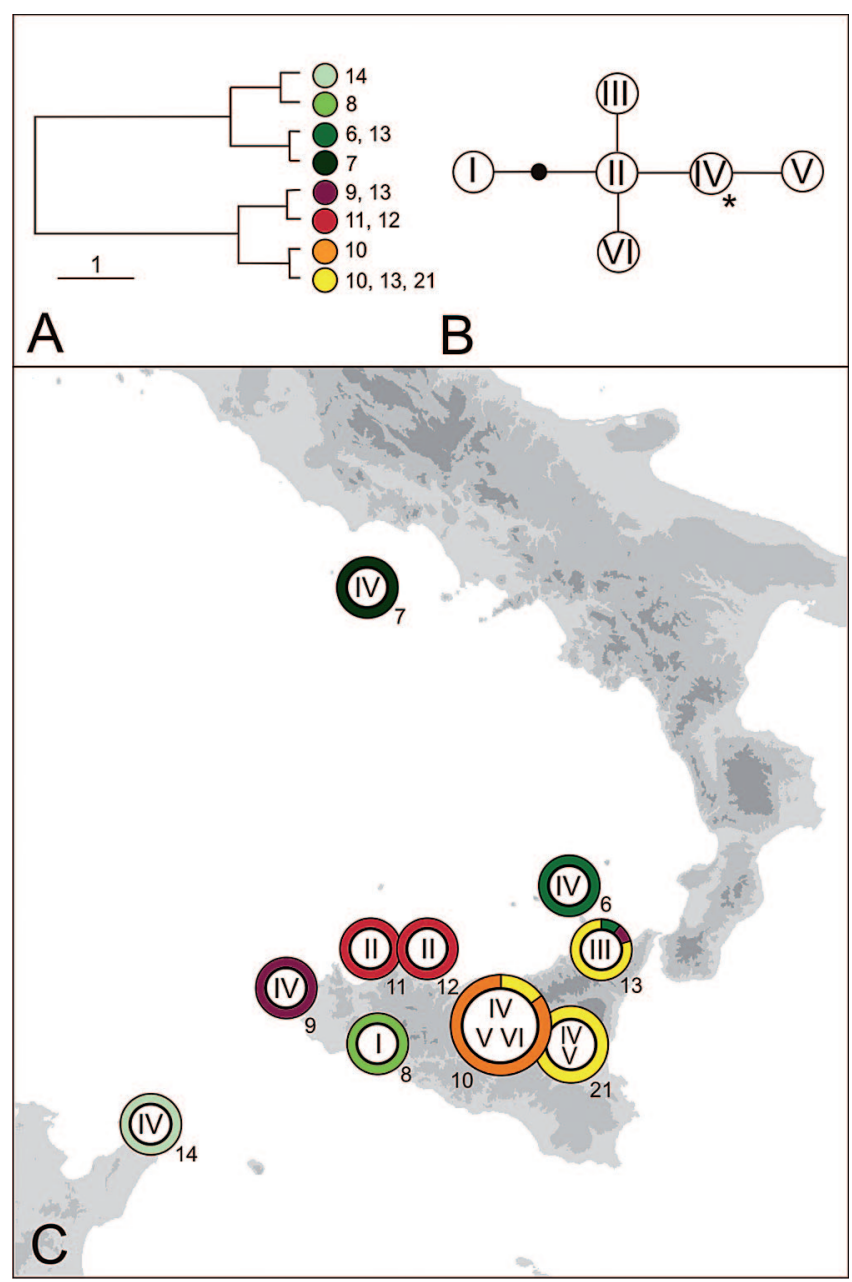

Table 2. List of haplotypes in the studied populations of the Sicily group and in Centaurea argentea with indication of nucleotide site variation within the chloroplast region $r p l 32-\operatorname{trn} L$.

\begin{tabular}{|c|c|c|c|c|c|c|c|c|c|c|}
\hline Haplotype & $\begin{array}{ll}2 & 2 \\
4 & 9 \\
7 & 6\end{array}$ & $\begin{array}{ll}2 & 3 \\
9 & 9 \\
6 & 2\end{array}$ & $\begin{array}{l}4 \\
5 \\
8\end{array}$ & $502-514$ & $523-534$ & $\begin{array}{l}6 \\
3 \\
1\end{array}$ & $\begin{array}{l}6 \\
3 \\
2\end{array}$ & $\begin{array}{l}6 \\
3 \\
4\end{array}$ & $770-773$ & Taxon (population number) \\
\hline Haplotype II & A $\mathrm{T}$ & $\mathrm{T} \mathrm{G}$ & $\mathrm{A}$ & - & CTATAAGGATTT & $\mathrm{G}$ & G & A & GAAA & Centaurea panormitana $(11,12)$ \\
\hline Haplotype III & A C & G G & A & - & CTATAAGGATTT & G & G & A & GAAA & Centaurea panormitana subsp. seguenzae (13) \\
\hline Haplotype V & A $\mathrm{T}$ & $\mathrm{T} \mathrm{G}$ & A & CTTCTTAАTTATC & CTATAAGGATTT & G & 0 & & - & Centaurea parlatoris (21) \\
\hline Haplotype VI & A $\mathrm{T}$ & $\mathrm{T} \mathrm{G}$ & A & - & CTATAAGGATTT & $\mathrm{G}$ & G & & GAAA & Centaurea busambarensis (10) \\
\hline $\begin{array}{l}\text { Haplotype } \\
\text { C. argentea }\end{array}$ & G $\mathrm{T}$ & $\mathrm{T} \mathrm{A}$ & A & CTTCTTAATTATC & - & $\mathrm{T}$ & G & $\mathrm{C}$ & GAAA & Centaurea argentea $(30)$ \\
\hline
\end{tabular}


It is known that AFLPs are no marker of choice for resolving relationships at deep nodes as the frequency of non-homologous fragments being scored as one AFLP band increases in parallel with the phylogenetic distance. The very limited plastid DNA variation, however, suggests that diversification within the group is recent and we therefore do not expect that our AFLP dataset contains much homoplasy. The molecular data suggest that the current taxonomic framework needs to be significantly revised. As taxonomic ranks should be applied in a comparable way throughout the entire genus once phylogenetic relationships are better understood and because a detailed morphometric analysis of the $C$. cineraria group is underway (Guarino, in prep.), we here refrain from taking taxonomic decisions but rather point out shortcomings of the presently used classification. (1) First of all, the lack of supported hierarchical structure in the AFLP dataset does neither support the division of the Acrolophus subgroup into sects. Acrolophus, Phalolepis and Willkommia (Candolle, 1838; Blanca, 1981) nor the division into informal groups as proposed by Pignatti (1982). It has been suggested that hybridisation and introgression within this group confound reconstruction of sectionial boundaries (Suárez-Santiago \& al., 2007b) but our data provide no evidence for this hypothesis. (2) It was previously shown (Schönswetter $\&$ al., 2009) that in groups that exhibit geographically isolated, fairly small populations and were suggested to have undergone relatively recent, synchronous, allopatric differentiation, geographically close populations tend to be related independent of their taxonomic assignment, the latter often being based on a single or very few characters only. As our data strongly suggest recent diversification in the $C$. cineraria group and because populations are often small, allowing for rapid fixation of probably parallely evolving characters, we expect that entirely morphology-based classifications such as those by Dostál (1976) and Pignatti (1982) are suited for practical purposes but do not reflect a natural system. This is well illustrated by the morphologically divergent $C$. parlatoris that was previously assigned to the $C$. dissecta group. It is not only deeply nested in the Sicily group but is also genetically only weakly differentiated from its next relative, C. busambarensis (Fig. 2), growing in geographic proximity. (3) Taxonomic ranks used for members of the Sicily group and for $C$. cineraria do not reflect observed patterns of genetic divergence. For example, the four investigated populations of $C$. cineraria subsp. cineraria are strongly reciprocally divergent and do not even form a monophyletic group; their genetic differentiation is at least as strong as that among the constituents of the Sicily group classified at specific level (Fig. 2). It is unclear if this pattern is exclusively caused by genetic drift in small, geographically isolated populations or if facultative apospory previously reported in C. cineraria (CelaRenzoni \& Viegi, 1982) also plays a role. (4) Of the remaining three species previously included in the $C$. cineraria group, C. veneris from the northern Tyrrhenian is more closely related to the C. paniculata group (Fig. 2). Centaurea gymnocarpa and C. leucadea, in contrast, clearly fall outside both groups. Centaurea leucadea groups with weak support with two members of sect. Phalolepis (C. deusta, C. scillae). In consequence, similarities of $C$. gymnocarpa, C. leucadea and C. veneris to
C. cineraria might be caused by convergence or by gene flow between these groups. The later hypothesis is supported by the presence of morphologically intermediate individuals in some populations not included in this study (A. Hilpold, pers. obs.). (5) As a minor point, the subspecies of $C$. panormitana are highly doubtful. On Mt. Pellegrino, where all three subspecies should occur, neither morphological differentiation was possible (A. Hilpold, pers. obs.) nor did the AFLP data suggest any differentiation. In contrast, subsp. seguenzae is morphologically separated by prolonged bract appendages and is clearly not the next relative of the other subspecies (Fig. 2).

In conclusion, our study shows that diversification in groups that - based on their highly disjunct distribution - were assumed to be old relics may be surprisingly recent. A further example for a recent, homoploid diversification in the Mediterranean is provided by the genus Nigella L. in the Aegean (Bittkau \& Comes, 2008). Moreover, it becomes more and more apparent that disregarding the "flat tail of the dispersal curve" might lead to erroneous conclusions regarding the evolutionary significance of long-distance seed dispersal. As illustrated by the $C$. cineraria group, this concerns not only species with diaspores that are morphologically adapted to dispersal, but also those which are lacking such adaptations. As a consequence, we could reconstruct a large number of biogeographic processes, i.e., various allopatric-vicariant divergences in Sicily as well as transoceanic dispersal across the Strait of Sicily and between the geographically distant but edaphically similar volcanic islands Lipari and Ventotene in the Tyrrhenian Sea.

\section{ACKNOWLEDGEMENTS}

Financial support from the Spanish Ministry of Education and Science (Project CGL2007-60781/BOS) and the Generalitat de Catalunya (Ajuts a Grups de Recerca Consolidats 2009/SGR/00439) is gratefully acknowledged. A. Hilpold benefited from a predoctoral grant of the JAE program (CSIC). Special thanks go to the Parco Nazionale della Majella (prot. n. 1763), to the Parco Naturale Regionale di Porto Venere (prot. n. 2804), to the Parco Nazionale Arcipelago Toscano (prot. n. 3363), to the Parco della Madonie (prot. n. 2195), to the Parco Nazionale delle Cinque Terre (prot. n. 2137), to the Parco Nazionale del Circeo (prot. n. PNC/2008/196) and to the Riserva Naturale delle Gole del Sagittario (prot. n. 1081) for the permission to collect plants in their territory. M. Galbany-Casals and A. Romo are acknowledged for their help in collecting specimens, K. Bardy for her help in preparing Fig. 1, and G.M. Schneeweiss for helping with the software BEAST. We are grateful to three anonymous reviewers, who provided insightful comments on a previous version of the manuscript.

\section{口 LITERATURE CITED}

Arrigoni, P.V. 2003. Le centauree Italiane del Gruppo "Centaurea paniculata L." Parlatorea 6: 49-78.

Astis, G. de, La Volpe, L. \& Peccerillo, A. 1997. Volcanological and petrological evolution of Vulcano Island (Aeolian arc, southern Tyrrhenian Sea). J. Geophys. Res. 102: 8021-8050.

Bancheva, S., Geraci, A. \& Raimondo, F.M. 2006. Genetic diversity 
in the Centaurea cineraria group (Compositae) in Sicily using isozymes. Pl. Biosyst. 140: 10-16.

Barca, D. \& Ventura, G. 1991. Volcano-tectonic evolution of Salina Island (Aeolian Archipelago, South Tyrrhenian Sea). Mem. Soc. Geol. Ital. 47: 401-415.

Bellucci, F., Lirer, L. \& Munno, R. 1999. Geology of Ponza, Ventotene and Santo Stefano islands (with a 1:15,000 scale geological map). Acta Vulcanol. 11: 197-222.

Bittkau, C. \& Comes H.P. 2008. Molecular inference of a Late Pleistocene diversification shift in Nigella s. lat. (Ranunculaceae) resulting from increased speciation in the Aegean archipelago. J. Biogeogr. 36: 1346-1360.

Blanc, P.L. 2002. The opening of the Plio-Quaternary Gibraltar Strait: Assessing the size of a cataclysm. Geodinam. Acta 15: 303-317.

Blanca, G. 1981. Origen, evolución y endemismo en la sección Willkommia G. Blanca (gén. Centaurea L.). Anales Jard. Bot. Madrid 37: 607-618.

Blondel, J. \& Aronson, J. 1999. Biology and wildlife of the Mediterranean region. Oxford: Oxford Univ. Press.

Bonfiglio, L., Mangano, G., Marra, A.C., Masini, F., Pavia, M. \& Petruso, D. 2002. Pleistocene Calabrian and Sicilian bioprovinces. Geobios (Lyon) 35: 29-39.

Bonin, A., Bellemain, E., Eidesen, P.B., Pompanon, F., Brochmann, C. \& Taberlet, P. 2004. How to track and assess genotyping errors in population genetic studies. Molec. Ecol. 13: 3261-3273.

Breitwieser, I. \& Podlech, D. 1986. Die Gattung Centaurea L. sect. Willkommia G. Blanca in Nord-Afrika. Mitt. Bot. Staatssamml. München 22: 21-96.

Busack, S.D. \& Lawson, R. 2008. Genetic differentiation of three species of Matthiola (Brassicaceae) in the Sicilian insular system. Biol. J. Linn. Soc. 94: 445-461.

Bussell, J.D., Waycott, M. \& Chappill, J.A. 2005. Arbitrarily amplified DNA markers as characters for phylogenetic inference. Perspect. Pl. Ecol. Evol. Syst. 7: 3-26.

Butler, R.W.H., McClelland, E. \& Jones, R.E. 1999. Calibrating the duration and timing of the Messinian salinity crisis in the Mediterranean: Linked tectonoclimatic signals in thrust-top basins of Sicily. J. Geol. Soc. London 156: 827-835.

Candolle, A.P. de. 1838. Prodromus systematis naturalis regni vegetabilis, vol. 6. Paris: Treuttel et Würtz.

Cano-Maqueda, J., Talavera, S., Arista, M. \& Catalán, P. 2008. Speciation and biogeographical history of the Campanula lusitanica complex (Campanulaceae) in the Western Mediterranean region. Taxon 57: 1252-1266

Cela-Renzoni, G. \& Viegi, L. 1982. Centaurea cineraria s.l. (Asteraceae) in Italia: Revisione citotassonomica. Atti Soc. Tosc. Sci. Nat. Pisa Mem., Ser. B 39: 99-144.

Clement, M., Posada, D. \& Crandall, K.A. 2000. TCS: A computer program to estimate gene genealogies. Molec. Ecol. 9: 1657-1660.

Colas, B., Olivieri, I. \& Riba, M. 1997. Centaurea corymbosa, a cliffdwelling species tottering on the brink of extinction: A demographic and genetic study. Proc. Natl. Acad. Sci. U.S.A. 29: 3471-3476.

Conti, F., Abbate, G., Alessandrini, A. \& Blasi, C. (eds.). 2005. An annotated checklist of the Italian vascular flora. Roma: Palombi Editori.

Corander, J. \& Marttinen, P. 2006. Bayesian identification of admixture events using multilocus molecular markers. Molec. Ecol. 15: 2833-2843.

Corander, J. \& Tang, J. 2007. Bayesian analysis of population structure based on linked molecular information. Math. Biosci. 205: 19-31

Corander, J., Waldmann, P., Marttinen, P. \& Sillanpää, M.J. 2004. BAPS 2: Enhanced possibilities for the analysis of genetic population structure. Bioinformatics 20: 2363-2369.

Crisci, G.M, Derosa, R., Esperanca, S., Mazzuoli, R. \& Sonnino, M. 1991. Temporal evolution of a 3 component system - the island of Lipari (Aeolian Arc, Southern Italy). Bull. Volcanol. 53: 207-221.

Damboldt, J. \& Matthäs, U. 1975. Chromosomenzahlen einiger mediterraner und mitteleuropäischer Centaurea-Arten (Asteraceae). Pl. Syst. Evol. 123: 107-115.

Dostál, J. 1976. Centaurea L. Pp. 254-301 in: Tutin, T.G., Heywood, V.H., Burges, N.A., Moore, D.M., Valentine, D.H., Walters, S.M. \& Webb, D.A. (eds.), Flora europaea, vol. 4. Cambridge: Cambridge Univ. Press.

Doyle, J.J. \& Doyle, J.L. 1987. A rapid DNA isolation procedure for small amounts of fresh leaf tissue. Phytochem. Bull. 19: 11-15.

Drummond, A.J. \& Rambaut, A. 2007. BEAST: Bayesian evolutionary analysis by sampling trees. BMC Evol. Biol. 7: 214. DOI: 10.1186/1471-2148-7-214.

Ferrarini, E. 1971. Flora dell isole Palmaria e Tino (Golfo della Spezia) Giorn. Bot. Ital. 105: 237-279.

Font, M., Garcia-Jacas, N., Vilatersana, R., Roquet, C. \& Susanna, A. 2009. Evolution and biogeography of Centaurea section Acrocentron inferred from nuclear and plastid DNA sequence analyses. Ann. Bot. (Oxford) 103: 985-997.

Garcia-Castellanos, D., Estrada, F., Jiménez-Munt, I., Gorini, C., Fernàndez, M., Vergés, J. \& De Vicente, R. 2009 Catastrophic flood of the Mediterranean after the Messinian salinity crisis. $\mathrm{Na}$ ture 462: 778-781.

Garcia-Jacas, N., Uysal, T., Romashchenko. K., Suárez-Santiago, V.N., Ertuğrul, K. \& Susanna, A. 2006. Centaurea revisited: A molecular survey of the Jacea group. Ann. Bot. (Oxford) 98: 741-753.

Giardina, G., Raimondo, F.M. \& Spadaro, V. 2007. A catalogue of plants growing in Sicily. Bocconea 20: 1-582.

Goes, S., Giardini, D., Jenny, S., Hollenstein, C., Kahle, H.-G. \& Geiger, A. 2004. A recent tectonic reorganization in the southcentral Mediterranean. Earth Planet. Sci. Lett. 226: 335-345.

Greuter, W. 1991. Botanical diversity, endemism, rarity, and extinction in the Mediterranean area: An analysis based on the published volumes of Med-Checklist. Bot. Chron. (Patras) 10: 63-79.

Greuter W. (ed.). 2008. Med-Checklist: A critical inventory of vascular plants of the circum-mediterranean countries, vol. 2, Dicotyledones (Compositae). Palermo: OPTIMA Secretariat; Geneva: Med-Checklist Trust of OPTIMA; Berlin: Euro+Med Plantbase Secretariat.

Hall, T.A. 1999. BioEdit: A user-friendly biological sequence alignment editor and analysis program for Windows 95/98/NT. Nucleic Acids Symp. Ser. 41: 95-98.

Hardy, O.J., González-Martínez, S.C., Colas, B., Fréville, H., Mignot, A. \& Olivieri, I. 2004. Fine-scale genetic structure and gene dispersal in Centaurea corymbosa (Asteraceae). II. Correlated paternity within and among sibships. Genetics 168: 1601-1614.

Hilpold, A., Garcia-Jacas, N., Vilatersana, R. \& Susanna, A. 2009. Two additions to the Jacea-Lepteranthus complex: Parallel adaptation in the enigmatic species Centaurea subtilis and C. exarata. Collect. Bot. (Barcelona) 28: 19-30.

Hsü, K.J. 1972. When Mediterranean dried up. Sci. Amer. 227: 27-36.

Kenyon, N.H., Ivanov, M.K., Akhmetzhanov, A.M. \& Akhmanov, G.G. (eds.). 2003. Interdisciplinary Geoscience Research on the North East Atlantic Margin, Mediterranean Sea and Mid-Atlantic Ridge. IOC Technical Series 67. Paris: UNESCO.

Krijgsman, W., Hilgen, F.J., Raffi, I., Sierro, F.J. \& Wilson, D.S. 1999. Chronology, causes and progression of the Messinian salinity crisis. Nature 400: 652-655.

Lambeck, K., Antonioli, F., Purcell, A. \& Silenzi, S. 2004. Sea-level change along the Italian coast for the past 10,000 yr. Quatern. Sci. Rev. 23: 1567-1598.

Lambeck, K. \& Bard, E. 2000. Sea-level change along the French Mediterranean coast for the past 30,000 years. Earth Planet. Sci. Lett. 175: 203-222.

Lo Presti, R.M. \& Oberprieler, C. 2009. Evolutionary history, biogeography and eco-climatological differentiation of the genus Anthemis L. (Compositae, Anthemideae) in the circum-Mediterranean area. J. Biogeogr. 36: 1313-1332.

Lumaret, R., Mir, C., Michaud, H. \& Raynal, V. 2002. Phylogeo- 
graphical variation of chloroplast DNA in holm oak (Quercus ilex L.). Molec. Ecol. 11: 2327-2336.

Mansion, G., Rosenbaum, R., Schoenenberger, N., Bacchetta, G., Rosselló, J.A. \& Conti, E. 2008. Phylogenetic analysis informed by geological history supports multiple, sequential invasions of the Mediterranean basin by the Angiosperm family Araceae. Syst. Biol. 57: 269-285.

Martínez-Solano, I., Gonçalves, H.A., Arntzen, J.W. \& GarcíaParís, M. 2004. Phylogenetic relationships and biogeography of midwife toads (Discoglossidae: Alytes). J. Biogeogr. 31: 603-618.

Médail, F. \& Diadema, K. 2009. Glacial refugia influence plant diversity patterns in the Mediterranean Basin. J. Biogeogr. 36: $1333-1345$.

Médail, F. \& Quézel, P. 1997. Hot-spots analysis for conservation of plant biodiversity in the Mediterranean Basin. Ann. Missouri Bot. Gard. 84: 112-127.

Meulenkamp, J.E. \& Sissingh, W. 2003. Tertiary palaeogeography and tectonostratigraphic evolution of the Northern and Southern Peri-Tethys platforms and the intermediate domains of the AfricanEurasian convergent plate boundary zone. Palaeogeogr. Palaeoclimatol. Palaeoecol. 196: 209-228.

Myers, N., Mittermeier, R.A., Mittermeier, C.G., da Fonseca, G.A.B. \& Kent J. 2000. Biodiversity hotspots for conservation priorities. Nature 403: 853-858.

Nei, M. \& Li, W.-H. 1979. Mathematical model for studying genetic variation in terms of restriction endonucleases. Proc. Natl. Acad. Sci. U.S.A. 76: 5269-5273.

Ochsmann, J. 2000. Morphologische und molekularsystematische Untersuchungen an der Centaurea stoebe L.-Gruppe (Asteraceae - Cardueae) in Europa. Diss. Bot. 324: 1-242.

Ortiz, M.A., Tremetsberger, K., Stuessy, T.F., Terrab, A., GarcíaCastaño, J.L. \& Talavera, S. 2009. Phylogeographic patterns in Hypochaeris section Hypochaeris (Asteraceae, Lactuceae) of the western Mediterranean. J. Biogeogr. 36: 1384-1397.

Passalacqua, N.G., Peruzzi, L. \& Pellegrino, G. 2008. A biosystematic study of the Jacobaea maritima group (Asteraceae, Senecioneae) in the Central Mediterranean area. Taxon 57: 893-906.

Peruzzi, L. 2008. Notulae: 1472-1473. Centaurea lacaitae, Centaurea montaltensis (Asteraceae). In: Nepi, C., Peruzzi, L. \& Scoppola, A. (eds.), Notulae alla Checklist della flora italiana 5. Inform. Bot. Ital. 40: 114-115.

Pignatti, S. 1982. Flora d'Italia, vol. 3. Bologna: Edagricole.

Posada, D. \& Crandall, K.A. 1998. MODELTEST: Testing the model of DNA substitution. Bioinformatics 14: 817-818.

Pottier-Alapetite, G. 1981. Flore de la Tunisie, Angiospermes - Dicotylédones - Gamopetales. Tunis: Publications Scientifiques Tunisiennes-Programme Flore et Végétation Tunisiennes.

Quézel, P. 1985. Definition of the Mediterranean region and the origin of its flora. Pp. 9-24 in: Gómez-Campo, C. (ed.), Plant conservation in the Mediterranean area. Dordrecht: Junk.

Raimondo, F.M. \& Bancheva, S.T. 2004. Centaurea erycina (Asteraceae), a new species from NW-Sicily. Bocconea 17: 299-306.

Raimondo, F.M., Bancheva, S.T. \& Ilardi, V. 2004. Centaurea saccensis (Asteraceae), a new species from SW-Sicily. Bocconea 17: 293-298.

Raimondo, F.M., Gianguzzi, L. \& Ilardi, V. 1994. Inventario delle specie "a rischio" nella flora vascolare nativa della Sicilia. Quad. Bot. Ambientale Appl. 3: 65-132.

Rohling, E.J., Fenton, M., Jorissen, F.J., Bertrand, P., Ganssen, G. \& Caulet, J.P. 1998. Magnitudes of sea-level lowstands of the past 500,000 years. Nature 394: 162-165.

Sánchez, J.L., Domina, G. \& Caujapé-Castells, J. 2005. Genetic differentiation of three species of Matthiola (Brassicaceae). Pl. Syst. Evol. 253: 81-93.

Sanmartín, I. 2003. Dispersal vs. vicariance in the Mediterranean: Historical biogeography of the Palearctic Pachydeminae (Coleoptera, Scarabaeoidea). J. Biogeogr. 30: 1883-1897.
Schönswetter, P., Solstad, H., García, P.E. \& Elven, R. 2009. A combined molecular and morphological approach to the taxonomically intricate European mountain plant Papaver alpinum s.l. (Papaveraceae) - taxa or informal phylogeographical groups? Taxon 58: $1326-1343$.

Shaw, J., Lickey, E.B., Schilling, E.E. \& Small, R.L. 2007. Comparison of whole chloroplast genome sequences to choose noncoding regions for phylogenetic studies in angiosperms: The tortoise and the hare III. Amer. J. Bot. 94: 275-288.

Siani, S., Sulpizio, R., Paterne, M. \& Sbrana, A. 2004. Tephrostratigraphy study for the last $18,00014 \mathrm{C}$ years in a deep-sea sediment sequence for the South Adriatic. Quatern. Sci. Rev. 23: 2485-2500.

Smith, C.I., Pellmyr, O., Althoff, D.M., Balcázar-Lara, M., LeebensMack, J. \& Segraves, K.A. 2008. Pattern and timing of diversification in Yucca (Agavaceae): specialized pollination does not escalate rates of diversification. Proc. Roy. Soc. London, Ser. B, Biol. Sci. 275: 249-258.

Speranza, F., Villa, I.M., Sagnotti, L., Florindo, F., Cosentino, D., Cipollari, P. \& Mattei, M. 2002. Age of the Corsica-Sardinia rotation and Liguro-Provençal Basin spreading: New paleomagnetic and Ar/Ar evidence. Tectonophysics 347: 231-251.

Stöck, M., Sicilia, A., Belfiore, N.M., Buckley, D., Lo Brutto, S., Lo Valvo, M. \& Arculeo, M. 2008. Post-Messinian evolutionary relationships across the Sicilian channel: Mitochondrial and nuclear markers link a new green toad from Sicily to African relatives. BMC Evol. Biol. 8: 56. DOI: 10.1186/1471-2148-8-56.

Suárez-Santiago, V.N., Blanca, G., Ruiz-Rejón, M. \& GarridoRamos, M.A. 2007a. Satellite-DNA evolutionary patterns under a complex evolutionary scenario: The case of Acrolophus subgroup (Centaurea L., Compositae) from the western Mediterranean. Gene 404: 80-92.

Suárez-Santiago, V.N., Salinas, M.J., Garcia-Jacas, N., Soltis, P.S., Soltis, D.E. \& Blanca, G. 2007b. Reticulate evolution in the Acrolophus subgroup (Centaurea L., Compositae) from the western Mediterranean: Origin and diversification of section Willkommia Blanca. Molec. Phylog. Evol. 43: 156-172.

Suc, J.P. 1984. Origin and evolution of the Mediterranean vegetation and climate in Europe. Nature 307: 429-432.

Tel-Zur, N., Abbo, S., Mysladbodski, D. \& Mizrahi, Y. 1999. Modified CTAB procedure for DNA isolation from epiphytic cacti of genera Hylocereus and Selenicereus (Cactaceae). Pl. Molec. Biol. Reporter 17: 249-254.

Thiede, J. 1978. A glacial Mediterranean. Nature 276: 680-683.

Thompson, J.D. 2005. Plant evolution in the Mediterranean. Oxford: Oxford Univ. Press.

Turland, N.J. \& Chilton, L. 2000. A revision of Centaurea argentea (Compositae, Cardueae), an endemic species of Kriti and Kithira (Greece). Bot. Chron. (Patras) 13: 71-79.

Van de Peer, Y. \& De Wachter, R. 1997. Construction of evolutionary distance trees with TREECON for Windows: Accounting for variation in nucleotide substitution rate among sites. Computer Appl. Biosci. 13: 227-230.

Veith, M., Mayer, C., Samaroui, B., Barroso, D.D. \& Bogaerts, S. 2004. From Europe to Africa and vice versa: Evidence for multiple intercontinental dispersal in ribbed salamanders (Genus Pleurodeles). J. Biogeogr. 31: 159-171.

Vos, P., Hogers, R., Bleeker, M., Reijans, M., Van de Lee, T., Hornes, M., Frijters, A., Pot, J., Paleman, J., Kuiper, M. \& Zabeau, M. 1995. AFLP: A new technique for DNA fingerprint. Nucleic Acids Res. 23: 4407-4414.

Yamane, K., Yasui, Y. \& Ohnishi, O. 2003. Intraspecific cpDNA variations of diploid and tetraploid perennial buckwheat, Fagopyrum cymosum (Polygonaceae). Amer. J. Bot. 90: 339-346.

Zhang, Q., Liu, Y. \& Sodmergen. 2003. Examination of the cytoplasmic DNA in male reproductive cells to determine the potential for cytoplasmic inheritance in 295 angiosperm species. Pl. Cell Physiol. 44: 941-951. 